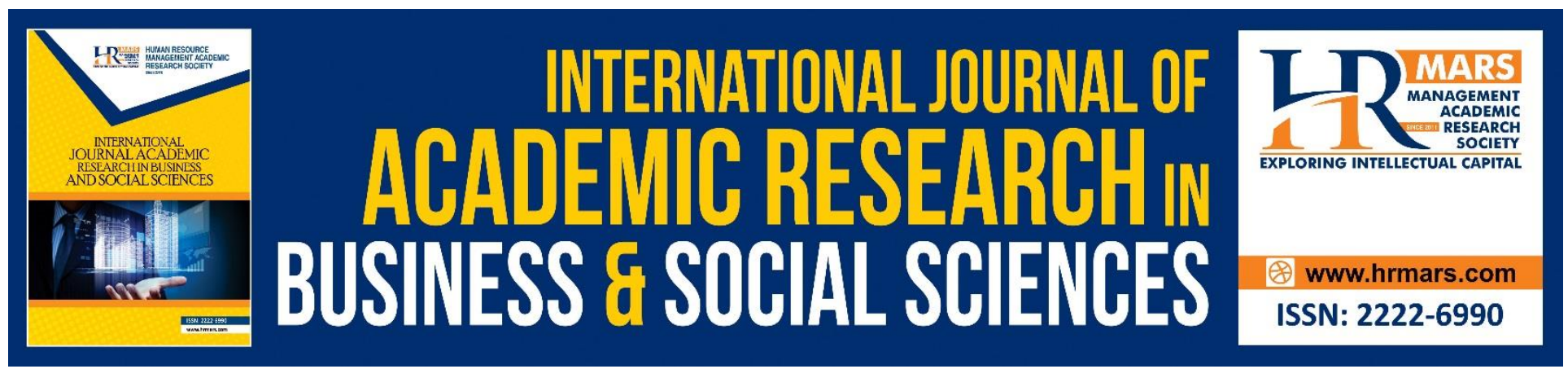

\title{
Practice of Fostering 4Cs Skills in Teaching and Learning
}

\author{
Norazlin Mohd Rusdin, Siti Rahaimah Ali
}

To Link this Article: http://dx.doi.org/10.6007/IJARBSS/v9-i6/6063

DOI: 10.6007/IJARBSS/v9-i6/6063

Received: 08 April 2019, Revised: 14 May 2019, Accepted: 02 June 2019

Published Online: 26 June 2019

In-Text Citation: (Rusdin \& Ali, 2019)

To Cite this Article: Rusdin, N. M., \& Ali, S. R. (2019). Practice of Fostering 4Cs Skills in Teaching and Learning. International Journal of Academic Research in Business and Social Sciences, 9(6), 1021-1035.

Copyright: (C) 2019 The Author(s)

Published by Human Resource Management Academic Research Society (www.hrmars.com)

This article is published under the Creative Commons Attribution (CC BY 4.0) license. Anyone may reproduce, distribute, translate and create derivative works of this article (for both commercial and non-commercial purposes), subject to full attribution to the original publication and authors. The full terms of this license may be seen at: http://creativecommons.org/licences/by/4.0/legalcode

Vol. 9, No. 6, 2019, Pg. 1021 - 1035

Full Terms \& Conditions of access and use can be found at http://hrmars.com/index.php/pages/detail/publication-ethics 


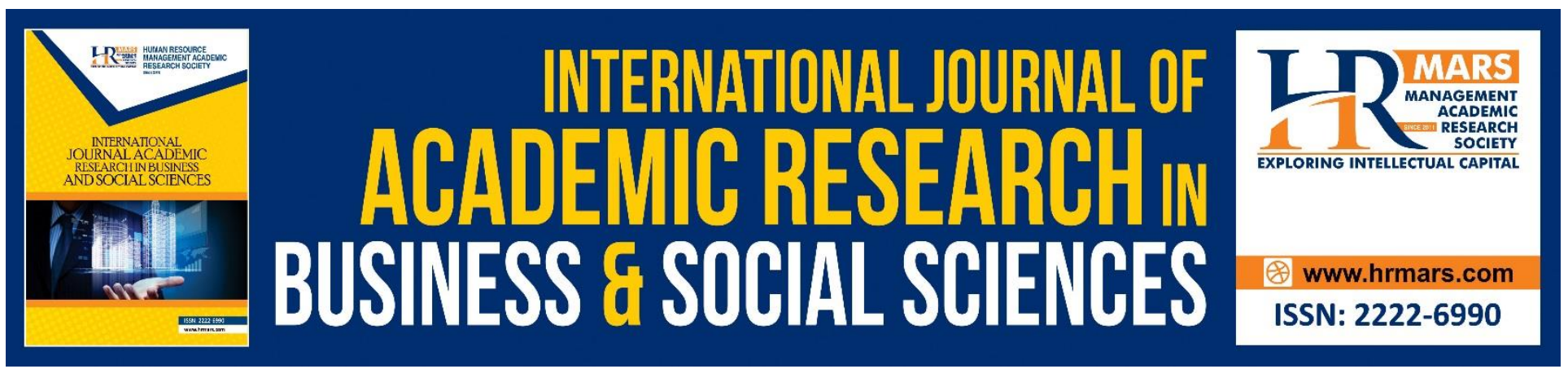

\title{
Practice of Fostering 4Cs Skills in Teaching and Learning
}

\author{
Norazlin Mohd Rusdin, Siti Rahaimah Ali \\ Fakulti Pembangunan Manusia, Universiti Pendidikan Sultan Idris, Tanjung Malim, Perak \\ Malaysia \\ Email: norazlinrusdin@gmail.com, siti.rahaimah@fpm.upsi.edu.my
}

\begin{abstract}
Mastering 4Cs skills which consist of critical thinking, communication, collaboration and creativity has become an important agenda in $21^{\text {st }}$ century learning and education based on 4.0 revolutions. Therefore, this study was carried out to identify level of practice of fostering 4Cs skills in teaching and learning. This study was implemented on 84 teachers as they answered the questionnaire provided. According to descriptive analysis which applied calculation of mean and standard deviation, respondents were found to state agreement at high level in average on three of the 4Cs skills namely critical thinking (Min =3.56), collaboration (Min = 4.02) and creativity (3.72) while moderate level on communication skill (Min =3.25). The findings show that it is necessary to put great effort on teaching and learning in order to ensure the process of fostering 4Cs skills can happen optimally so that pupils will be able to master the skills effectively.
\end{abstract}

Keywords: 4Cs Skills, Critical Thinking, Communication, Collaboration, Creativity, Teaching and Learning

\section{Introduction}

Start from 2017, Malaysia Ministry of Education (MMOE) introduced Standard Curriculum of Primary School (Revised) in attempt to bring $21^{\text {st }}$ century learning into reality. Therefore, there are 4 skills (4Cs skills) in $21^{\text {st }}$ century learning consists of critical thinking, communication, collaboration and creativity that significantly important to be mastered by pupils (Buletin Anjakan Buletin Transformasi Pendidikan Malaysia Bil. 4/2015)

These 4Cs skills also emphasized as super skills by educational system around the world (CCSS, 2014; ISTE, 2007). The responsibility of fostering 4Cs skills is a vital task in attempt to achieve MMOE's vision as cited in Pelan Pembangunan Pendidikan Malaysia (PPPM) 2013-2025. For the time being, the focus of fostering 4Cs skills become an important agenda where MMOE as the main authority of national education development has derived its own definition regarding $21^{\text {st }}$ century learning and 4Cs skills (MMOE, 2017). MMOE (2017) defining $21^{\text {st }}$ century learning as a learning process which is 
INTERNATIONAL JOURNAL OF ACADEMIC RESEARCH IN BUSINESS AND SOCIAL SCIENCES

Vol. 9, No. 6, June, 2019, E-ISSN: 2222-6990 (C) 2019 HRMARS

student-centred based on elements consist of communication, collaboration, critical thinking and creativity as well as applying values and ethics. Malaysia Ministry of Education (2017) has defined each of 4Cs skills as cited in the following Table 1.

Table 1: Definition of 4Cs Skills According to Malaysia Ministry of Education (2017)

\begin{tabular}{|l|l|}
\hline \multicolumn{1}{|c|}{ Skill } & \multicolumn{1}{c|}{ Definition } \\
\hline Communication & $\begin{array}{l}\text { Interaction between teacher-student, student-student and student- } \\
\text { resource occur verbally or non-verbally to convey knowledge what they } \\
\text { have understood and share knowledge with friends. }\end{array}$ \\
\hline Collaboration & $\begin{array}{l}\text { Cooperation and consensus occur between teacher-student and student- } \\
\text { student actively and comprehensively that enable change of idea and } \\
\text { opinion among the students. }\end{array}$ \\
\hline Critical thinking & $\begin{array}{l}\text { The exploration of thinking happens to evaluate any idea logically and } \\
\text { rationally in order to make reasonable decision by providing acceptable } \\
\text { reason and proof. }\end{array}$ \\
\hline Creativity & $\begin{array}{l}\text { Process of applying idea to produce innovative product, activity and } \\
\text { project which are new, useful and quality. }\end{array}$ \\
\hline
\end{tabular}

Malaysia Ministry of Education (2017) has brought out the characteristics of effective mastery on 4Cs skills. These characteristics are elaborated as shown in Table 2. 
INTERNATIONAL JOURNAL OF ACADEMIC RESEARCH IN BUSINESS AND SOCIAL SCIENCES

Vol. 9, No. 6, June, 2019, E-ISSN: 2222-6990 @ 2019 HRMARS

Table 2: Characteristics of Effective Mastery on 4Cs Skills

\begin{tabular}{|c|c|}
\hline Skill & Characteristics of Effective Mastery \\
\hline Communication & $\begin{array}{l}\text { 1. Student able to observe, obtain and giving feedback to other } \\
\text { people. } \\
\text { 2. Student able to organize their thinking logically and state their ideas } \\
\text { clearly and concisely. } \\
\text { 3. Student able to understand how to accommodate a message with } \\
\text { certain method of delivering it. } \\
\text { 4. Student interacts with their friends confidently during imparting any } \\
\text { topic. }\end{array}$ \\
\hline Collaboration & $\begin{array}{l}\text { 1. Students with different capability cooperate to achieve the same } \\
\text { goal and depend on each other to succeed. } \\
\text { 2. Students are responsible to any task given within a group as well as } \\
\text { appreciate contribution and ideas from their friends. } \\
\text { 3. Students get involve in harmony within their group through task } \\
\text { distribution based on students' capability. } \\
\text { 4. Students able to accept and respect opinion of others, flexible and } \\
\text { willing to tolerate in attempt to achieve the same goal. }\end{array}$ \\
\hline Critical thinking & $\begin{array}{l}\text { 1. Students possess information which is relevant to various things } \\
\text { and fields. } \\
\text { 2. Students explore a field of knowledge through reading, inquiring } \\
\text { and carry out hands-on activity to gain knowledge. } \\
\text { 3. Students make decision based on information and able to defend it } \\
\text { by providing proof. } \\
\text { 4. Students are open minded, willing to accept opinion of others and } \\
\text { humble. }\end{array}$ \\
\hline Creativity & $\begin{array}{l}\text { 1. Students see current situation from various angles to generate ideas } \\
\text { and doing something in different way. } \\
\text { 2. Students produce and utilize new ideas in certain context and bring } \\
\text { out positive outcome. } \\
\text { 3. Students are daring to try and encouraged not to get worry toward } \\
\text { critics. } \\
\text { 4. Students have clear vision and authentic imagination as well as } \\
\text { follow the common rules. }\end{array}$ \\
\hline
\end{tabular}

MMOE (2017) has come out with a guide of implementation of learning based on 4Cs skills with aspiration to improve teachers' understanding toward this education reformation. With deep understanding, teachers supposed to be able to enhance their teaching practice that fulfil $21^{\text {st }}$ century education agenda and in further increase the effectiveness of fostering 4Cs skills in the classroom. Other than MMOE, there are sources from local authority and foreign countries that also defining, elaborating and producing the framework of 4Cs skills, comprising Partnership of $21^{\text {st }}$ Century (2009; 2015), National of Education Association (2010), Ontario Ministry of Education (2016), 
INTERNATIONAL JOURNAL OF ACADEMIC RESEARCH IN BUSINESS AND SOCIAL SCIENCES

Vol. 9, No. 6, June, 2019, E-ISSN: 2222-6990 @ 2019 HRMARS

Berryssa United School District (2015), Kivunja (2015.a) and State Education Department of Johor (2017).

\section{Background and Problem Statement}

Data collected by Collegiate Learning Assessment found that students in colleges did not obtain significant statistical performance in critical thinking, complex reasoning as well as writing communication (Arum \& Roksa, 2011; Levin-Goldberg, 2012). There are a lot of pedagogical evidences based on research show that interaction and transaction in communication skill are necessary for pupils to be succeed, not only in the classroom but in real life after school as well (Coulson, 2006; Cruickshank \& Kennedy, 1986; Muijs \& Reynolds, 2011; Wragg, 1984; Kivunja, 2015.b). In The World Beyond the Classroom, Gerald (2015) mentioned communication as a super skill in the world since thoughts, inquiries and solutions can be shared through communication. In the competitive world nowadays, communication is the second most important element after someone education qualification to be assessed in career especially for the business-oriented post. Therefore, the capability to communicate effectively is the most important life skill.

Positive result of collaboration toward pedagogical practice, pupils' administration and professional collaboration has been found by Stephanie Vanhover and Brownell et al (2006) in University of Florida in a joint study on collaboration. Many experts in this field including Kagan (1994), Johnson and Johnson (2009) as well as Killen (2013) had strictly stated the important of collaboration in increasing competencies of teaching and learning as well as in life journey after school.

Terms of creativity and innovation often used when refer to exploitation of new ideas consciously or create new usage of ideas in order to increase the social and economic values (Wessel, 2009; Beghetto \& Kaufman, 2014). Partnership for 21 $1^{\text {st }}$ Century (2014) emphasized that current economy is driven by information as well as creativity and innovation in digital technology as the main key of global economy. In facts, the importance of creativity and innovation has become the main essence for human to well survive as De Bono (1995) mentioned that creativity is the main resource for a human above everything. Without creativity, no progress can be achieved and the same pattern will be kept repeating again and again, forever. Partnership for $21^{\text {st }}$ Century (P21, 2012) also emphasized on the importance of creativity and innovation as one of 4Cs skills that is a vital needs to successfully adapt in modern life. It is a crucial effort to teach creativity skill in the best way because of its complex impact and feature that connecting three important components consist of knowledge, creative thinking and motivation (Adams, 2006).

Even though, there is a significant needs to re-evaluate and enhance teaching practice according to current change, however form past till now many of the teachers are still practising traditional method of teaching with teacher-centred strategy (Rajendran, 2001; Azmi \& Nurzatulshima, 2017) where the process of conveying content knowledge happen passively. As a result, pupils' engagement in learning are retarded and learning process become limited which causing the pupils unable to master knowledge and skills related to subject matter as well as 4 Cs skills 
optimally. Limited strategy, technique, method and approach applied by teacher drive to decrease of interest toward learning process among the pupils (Yunos, 2015) and also affecting the process of fostering 4Cs skills. Pupils are unable to integrate 4Cs skills in their learning process due to teachers' failure in fostering 4Cs skills (Mahamod, 2011).

Pupils should be given chances to get involve in various types of activities which encourage them work cooperatively in solving problem or carry out a task as a group work in order to promoting participation, performance and motivation in their learning (Alismail \& McGuire, 2015). A study carried out by Salehudin, Hassan and Hamid (2015) has proven that learning strategy and approach play important part in attracting pupils' interest toward subject as well as changing their views on subject difficulty.

\section{Instrument of Study}

This study utilised a set of questionnaire as instrument. The questionnaire was developed based on information provided by MMOE (2017) in Panduan Pelaksanaan Pembelajaran Abad Ke-21. The instrument internal consistency has been determined by calculating Cronbach's Alpha value through a statistical analysis by using Statistical Package for the Social Science (SPSS).

\section{Sampling}

Random sampling was applied in selecting the respondents of this study. 84 respondents have responded to the questionnaire provided. The respondents were consisting of male and female teachers from a number of states in Malaysia.

\section{Data Analysis}

The data obtained in this study were analysis according to two main parts demography of the respondents and respondents' responds toward 4Cs skills which have been elaborated for each skill respectively.

Demography of the respondents shows the information of respondents' background relating to gender, age and teaching experience. Table 3 shows frequency distribution of respondents according to gender.

Table 3: Frequency Distribution of Respondents According to Gender

\begin{tabular}{ccc}
\hline Gender & Frequency & Percentage (\%) \\
\hline Man & 24 & 28.6 \\
Woman & 60 & 71.4 \\
\hline Total & 84 & 100.0 \\
\hline
\end{tabular}

According to Table 3, this study has involved 84 respondents consist of 24 male respondents (28.6\%) and 60 female respondents (71.4\%). Next, Table 4 shows frequency distribution of respondents according to age. 
INTERNATIONAL JOURNAL OF ACADEMIC RESEARCH IN BUSINESS AND SOCIAL SCIENCES Vol. 9, No. 6, June, 2019, E-ISSN: 2222-6990 @ 2019 HRMARS

Table 4: Frequency Distribution of Respondents According to Age

\begin{tabular}{ccc}
\hline Age & Frequency & Percentage (\%) \\
\hline 21-30 years & 3 & 3.6 \\
31-40 years & 54 & 64.3 \\
41-50 years & 27 & 32.1 \\
\hline
\end{tabular}

Table 4 shows that respondents can be categorized into three classes of age where 3 (3.6\%) respondents were in the range of age 21 to 30 years old, 54 (64.3\%) respondents were in the range of age 31 to 40 years old while the rest 27 (32.1\%) respondents were in the range of age 41 to 50 years old.

Table 5 shows frequency distribution of respondents according to teaching experience.

Table 5: Frequency distribution of respondents according to teaching experience

\begin{tabular}{ccc}
\hline Experience & Frequency & Percentage \\
\hline 1 to 10 years & 18 & 21.4 \\
11 to 20 years & 54 & 64.3 \\
21 to 30 years & 12 & 14.3 \\
\hline
\end{tabular}

From Table 5, 18 (21.4\%) of the respondents have been teaching in the range of 1 to 10 years, $54(64.3 \%)$ of the respondents were in the range of 11 to 20 years teaching experience while the other $12(14.3 \%)$ respondents have been teaching in the range of 21 to 30 years.

\section{Analysis on Respondents' Feedback toward 4Cs Skills}

This part of analysis has been carried out separately for each critical thinking, communication, collaboration and creativity skills. The questionnaire applied 5-point Likert Scale where each point represents different level of agreement as shown in Table 6.

Table 6: 5-point Likert scale

\begin{tabular}{ccccc}
\hline 1 & 2 & 3 & 4 & 5 \\
\hline $\begin{array}{c}\text { Very } \\
\text { inappropriate }\end{array}$ & Inappropriate & Neutral & Appropriate & Very appropriate \\
\hline
\end{tabular}


According to feedback gained from the respondents, value of mean will be generated by using descriptive analysis in SPSS. Value of mean obtained for each item then interpreted according to interpretation of mean by Torrefranca (2017) as shown in Table 7.

Table 7: Interpretation of mean value

\begin{tabular}{cc}
\hline Mean & Interpretation \\
\hline $1.00-1.49$ & Very low \\
$1.50-2.49$ & Low \\
$2.50-3.49$ & Fair \\
$3.50-4.49$ & High \\
$4.50-5.00$ & Very high \\
\hline
\end{tabular}

\section{Analysis of Respondents' Feedback toward Critical Thinking}

Internal consistency of items related to critical thinking has been determined by calculating the value of Cronbach's Alpha as shown in Table 8.

Table 8: Value of Cronbach's Alpha of Critical Thinking Items

\begin{tabular}{cc}
\hline Number of Item & Cronbach's Alpha \\
\hline 6 & 0.861 \\
\hline
\end{tabular}

Cronbach's Alpha value of 0.861 for items in critical thinking means that its internal consistency is high and acceptable. According to Taber (2018) and Tavakol and Dennick (2011) acceptable Cronbach' alpha value is 0.7 and above. Table 9 shows respondents' feedback toward statements related to critical thinking. 
INTERNATIONAL JOURNAL OF ACADEMIC RESEARCH IN BUSINESS AND SOCIAL SCIENCES Vol. 9, No. 6, June, 2019, E-ISSN: 2222-6990 @ 2019 HRMARS

Table 9: Respondents' Feedback toward Critical Thinking

\begin{tabular}{|l|c|c|c|}
\hline \multicolumn{1}{|c|}{ Statement } & $\begin{array}{c}\text { Mean } \\
\text { (M) }\end{array}$ & $\begin{array}{c}\text { Standard } \\
\text { Deviation } \\
\text { (SD) }\end{array}$ & $\begin{array}{c}\text { Interpretatio } \\
\mathrm{n}\end{array}$ \\
\hline $\begin{array}{l}\text { 1. Student possesses appropriate and adequate } \\
\text { information for their task. }\end{array}$ & 3.21 & 1.067 & Fair \\
\hline $\begin{array}{l}\text { 2. Student possesses skill in searching information. } \\
\text { 3. Student is encouraged to contribute different } \\
\text { opinion. }\end{array}$ & 3.29 & 1.084 & Fair \\
\hline $\begin{array}{l}\text { 4. Student looks something from different } \\
\text { perspective }\end{array}$ & 3.71 & 0.716 & High \\
\hline $\begin{array}{l}\text { 5. Student state reason or justification to support } \\
\text { his/her opinion or decision. }\end{array}$ & 3.46 & 0.999 & Faigh \\
\hline $\begin{array}{l}\text { 6. Student is given chance to argue other student's } \\
\text { opinion. }\end{array}$ & 3.64 & 0.951 & High \\
\hline \multicolumn{1}{|c|}{ AVERAGE } & 3.56 & 0.952 & High \\
\hline
\end{tabular}

The findings shows that respondents agreed at fair level for the three statements, pupils possess adequate and relevant for a task given $(M=3.21$; $S P=1.067)$, pupils possesses skill in searching information $(M=3.29 ; S P=1.084)$ and students were able to state reason or justification to support their opinion or decision ( $M=3.46$; $S P=0.999)$. As for the other three statements, respondents were agreed at high level of agreement where student is encouraged to contribute different opinion ( $M=4.07$; $S P=0.716)$, student looks something from different perspective $(M=$ 3.71; $\mathrm{SP}=0.897)$ and student is given chance to argue other student's opinion $(\mathrm{M}=3.64 ; \mathrm{SP}=0.951)$.

\section{Analysis of Respondents' Feedback toward Communication Skill}

Table 10 shows value of Cronbach's Alpha for items in communication skill and the result of 0.890 indicate that the items have high and acceptable internal consistency.

Table 10: Value of Cronbach's Alpha of Communication Items

\begin{tabular}{cc}
\hline Number of Item & Cronbach's Alpha \\
\hline 6 & 0.890 \\
\hline
\end{tabular}

Table 11 shows the findings obtained from respondents regarding to communication skill. 
INTERNATIONAL JOURNAL OF ACADEMIC RESEARCH IN BUSINESS AND SOCIAL SCIENCES

Vol. 9, No. 6, June, 2019, E-ISSN: 2222-6990 @ 2019 HRMARS

Table 11: Respondents' feedback toward communication skill

\begin{tabular}{|c|c|c|c|}
\hline Statement & $\begin{array}{l}\text { Mean } \\
(\mathrm{M})\end{array}$ & $\begin{array}{c}\text { Standard } \\
\text { Deviation } \\
\text { (SD) }\end{array}$ & $\begin{array}{c}\text { Interpretatio } \\
\mathrm{n}\end{array}$ \\
\hline 1. Students organize their presentation effectively. & 3.04 & 1.071 & Fair \\
\hline $\begin{array}{l}\text { 2. Students use clear body language, voice } \\
\text { intonation and writing. }\end{array}$ & 3.18 & 1.056 & Fair \\
\hline $\begin{array}{l}\text { 3. Students ask their friends whether they } \\
\text { understand their presentation. }\end{array}$ & 3.21 & 1.134 & Fair \\
\hline $\begin{array}{l}\text { 4. Students give feedback to the friends who are } \\
\text { disagreeing with their ideas or opinion. }\end{array}$ & 3.21 & 1.031 & Fair \\
\hline $\begin{array}{l}\text { 5. Students able to predict question that might be } \\
\text { asked according to their presentation. }\end{array}$ & 2.82 & 1.124 & Fair \\
\hline $\begin{array}{l}\text { 6. Teacher gives clue to answer unpredictable } \\
\text { question. }\end{array}$ & 4.04 & .793 & High \\
\hline $\begin{array}{ll}\text { AVERAGE } \\
\end{array}$ & 3.25 & 1.035 & Fair \\
\hline
\end{tabular}

From the interpretation of respondents' feedback as shown in Table 11, the respondents state agreement at high level only for item out of six items. Respondents were highly agree that Teacher gives clue to answer unpredictable question $(M=4.04 ; S D=0.793)$. In the other hand, respondents fairly agreed to the other five items consist of students organize their presentation effectively $(M=$ 3.04; $S P=1.071)$, students use clear body language, voice intonation and writing $(3.18 ; \mathrm{SP}=1.056)$, students ask their friends whether they understand their presentation $(M=3.21 ; S P=1.134)$, students give feedback to the friends who are disagree with their ideas or opinion $(\mathrm{M}=3.21$; $\mathrm{SP}=$ 1.031) and also students able to predict question that might be asked according to their presentation $(\mathrm{M}=2.82 ; \mathrm{SP}=1.124)$.

\section{Analysis of Respondents' Feedback toward Collaboration Skill}

Items related to collaboration skill possess high and acceptable internal consistency according to Cronbach's Alpha value shown in Table 12.

Table 12: Value of Cronbach's Alpha of Collaboration Items

\begin{tabular}{cc}
\hline Number of Item & Cronbach's Alpha \\
\hline 6 & 0.874 \\
\hline
\end{tabular}

Table 13 shows the findings of respondents' feedback upon statements related to collaboration skill. 
INTERNATIONAL JOURNAL OF ACADEMIC RESEARCH IN BUSINESS AND SOCIAL SCIENCES

Vol. 9, No. 6, June, 2019, E-ISSN: 2222-6990 @ 2019 HRMARS

Table 13: Respondents' Feedback toward Collaboration Skill

\begin{tabular}{|l|c|c|c|}
\hline \multicolumn{1}{|c|}{ Statement } & $\begin{array}{c}\text { Mean } \\
\text { (M) }\end{array}$ & $\begin{array}{c}\text { Standard } \\
\text { Deviation } \\
\text { (SD) }\end{array}$ & $\begin{array}{c}\text { Interpretatio } \\
\mathrm{n}\end{array}$ \\
\hline $\begin{array}{l}\text { 1. Tasks given need students to cooperate. } \\
\text { 2. Students comfort to discuss with friends. }\end{array}$ & 4.39 & 0.629 & High \\
\hline $\begin{array}{l}\text { 3. Students have close relationship among each } \\
\text { other in the group. }\end{array}$ & 3.75 & 0.637 & High \\
\hline $\begin{array}{l}\text { 4. Students get chance to give opinion and respect } \\
\text { to each other. }\end{array}$ & 3.75 & 0.887 & High \\
\hline $\begin{array}{l}\text { 5. Students show enthusiasm working as a team. } \\
\text { A. Teacher guides student to get involve in }\end{array}$ & 4.82 & 0.945 & High \\
\hline \multicolumn{1}{|c|}{ AVERAGE } & 4.02 & 0.747 & High \\
\hline
\end{tabular}

According to respondents' feedback mentioned in Table 13, the respondents were highly agree that tasks given need students to cooperate $(M=4.39 ; S P=0.629)$, student comfort to discuss with friends $(M=3.96 ; S P=0.637)$, student have close relationship among each other in the group $(\mathrm{M}=3.75 ; \mathrm{SP}=0.752)$, student get chance to give opinion and respect to each other $(\mathrm{M}=3.75 ; \mathrm{SP}=$ $0.887)$, student show enthusiasm working as a team $(M=3.82 ; S P=0.945)$ as well as teacher guide student to get involve in discussion $(M=4.43 ; \mathrm{SP}=0.634)$.

\section{Analysis of Respondents' Feedback toward Creativity}

According to Cronbach's Alpha value of 0.833 as shown in Table 14, the items of creativity have high and acceptable internal consistency.

Table 14: Value of Cronbach's Alpha of Creativity Items

\begin{tabular}{cc}
\hline Number of Item & Cronbach's Alpha \\
\hline 6 & 0.833 \\
\hline Table 15 shows the findings of respondents' feedback towards statements of creativity skill.
\end{tabular}

Table 15 shows the findings of respondents' feedback towards statements of creativity skill. 
INTERNATIONAL JOURNAL OF ACADEMIC RESEARCH IN BUSINESS AND SOCIAL SCIENCES

Vol. 9, No. 6, June, 2019, E-ISSN: 2222-6990 @ 2019 HRMARS

Table 15: Value of Cronbach's Alpha of Creativity Items

\begin{tabular}{|l|c|c|c|}
\hline \multicolumn{1}{|c|}{ Statement } & $\begin{array}{c}\text { Mean } \\
\text { (M) }\end{array}$ & $\begin{array}{c}\text { Standard } \\
\text { Deviation } \\
\text { (SD) }\end{array}$ & $\begin{array}{c}\text { Interpretatio } \\
\mathrm{n}\end{array}$ \\
\hline $\begin{array}{l}\text { 1. The features of product produced by student } \\
\text { are unique and authentic. }\end{array}$ & 3.54 & 0.744 & High \\
\hline $\begin{array}{l}\text { 2. Students are able to state justification of the } \\
\text { product they produced. }\end{array}$ & 3.46 & 0.838 & Fair \\
\hline $\begin{array}{l}\text { 3. Students are encouraged to give opinion toward } \\
\text { various aspects regarding to the lesson. }\end{array}$ & 3.79 & 0.738 & High \\
\hline $\begin{array}{l}\text { 4. Students are allowed to put on trials and make } \\
\text { mistake for learning purpose. }\end{array}$ & 3.89 & 0.916 & High \\
\hline $\begin{array}{l}\text { 5. Students are asked to state alternative idea and } \\
\text { give relevant justification. }\end{array}$ & 3.79 & 0.630 & High \\
\hline $\begin{array}{l}\text { 6. Other students also asked to give opinion } \\
\text { toward alternative idea of a student. }\end{array}$ & 3.86 & 0.848 & High \\
\hline \multicolumn{1}{|c|}{ AVERAGE } & 3.72 & 0.786 & High \\
\hline
\end{tabular}

The findings show that the respondents were fairly agree regarding to students ability in justification of the product they produce $(M=3.46$; $S P=0.838)$. However, the respondents show agreement at high level toward the rest statement of creativity where they highly agree that the features of product produce by student is unique and authentic $(M=3.54 ; S P=0.744)$, student are encouraged to give opinion toward various aspects $(M=3.79 ; S P=0.738)$, student are allowed to try and make mistake $(M=3.89 ; \mathrm{SP}=0.916)$, student are asked to state alternative idea and give relevant justification $(\mathrm{M}=3.79 ; \mathrm{SP}=0.630)$ and other students also asked to give opinion toward alternative idea of a student $(M=3.86 ; S P=0.848)$.

In general, we can conclude here that the practice of fostering 4Cs skills in teaching and learning process in the classroom reached fair level for communication skill and high level for critical thinking, collaboration and communication.

\section{Discussion}

The findings show that the classroom practice of fostering 4Cs skills in teaching and learning have not achieve the effective level yet as the respondents state agreement at fair level only for the most items related to critical thinking. Therefore, all the issues regarding to attempt of fostering $4 \mathrm{Cs}$ skills should be emphasized with adequate attention in order to enable students to master 4Cs skills effectively. Skill of searching information is reported to be at fair level only and it should not be abandoned due to importance of possessing information about many things may support the development of critical thinking (MMOE, 2017). There are many ways can be taken by teachers to promote students to explore information. Information exploration can be carried out through reading and asking important as well as useful questions by students (MMOE, 2017; P21, 2015; BUSD, 2016), 
implementing hands-on activities (MMOE, 2017) and collecting information by using variety of tools and resources including digital sources (Ontario Ministry of Education, 2016).

Respondents' feedbacks in this study also show agreement only at fair level for most items related to communication skill. These findings are matched to a report by The Conference Board et al (2006) as they state that there are evidence on students disability in mastering basic communication skill even though education always emphasizes on fluency in reading, accurate speech as well as clear writing. Since communication skill is significantly important in all fields, teacher should take action on more efficient ways of fostering this skill. Class discussion should be routine practice and classroom transformed into a community where ideas are discussed, expanded and understood (Bruce, 2007; Sinay \& Nahornick, 2016; BUSD, 2016). In further, teacher must observe the communication process among the students and provide appropriate feedback (Carter, 2014) to promote meaningful and effective communication in learning.

\section{Conclusion}

Practice of fostering 4Cs skills have not happen at optimum level yet may be due to challenges and constraint faced by teachers involving various aspects such as knowledge, understanding and skills related to effective strategy, method, technique and approached to be applied in teaching process. Support in term of professional development and pedagogy enhancement related to $21^{\text {st }}$ century learning and fostering 4Cs skills should be provided for all the teachers. This study suggests carrying out a development of pedagogy module based on 4Cs skills as a reference and guidance for teachers.

\section{Reference}

Adams, K. (2006). The Sources of Innovation and Creativity. National Center on Education and Economy.

Alismail, H. A., \& McGuire, P. (2015). 21st Century Standards and Curriculum: Current Research and Practice. Journal of Education and Practice, 6(6), 150-154.

Arum, R., \& Roksa, J. (2011). Measuring College Performance. Mapping Broad-Access Higher Education Conference, $1^{\text {st }}-2^{\text {nd }}$ December, 2011. Standford University.

Azmi, M. N., \& Nurzatulshima. (2017). Infusing High Order Thinking Skills: Teachers' Readiness in Teaching and Learning of Primary School Design and Technology Subject. International Research Journal of Education and Sciences (IRJES). Vol.1 Special Issue 1 (Malay).

Beghetto, R. A., \& Kaufman, J. C. (2014). Classroom Contexts for Creativity. High Abilities Studies, 25, 53-69.

Brownell, M. T., Adams, A., Sindelar, P., Wahdron, N., \& Vanhover, S. (2006). Learning ftom Collaboration: The Role of Teacher Qualities. Council for Exceptional Children, 72(2), 169-185.

Bruce, C. D. (2007). Student Interactionin the Math Classroom: Stealing Ideas or Building Understanding. What Works? Research into Practice. The Literacy and Numeracy Secretariat Ontario. Dicapai dari

http://www.edu.gov.on.ca/eng/literacynumeracy/inspire/research/bruce.pdf

Anjakan, B. (April, 2015). Ciri-ciri Pembelajaran Abad Ke-21. Buletin Transformasi Pendidikan Malaysia. Pelan Pembangunan Pendidikan Malaysia 2013-2025, p.2. 
INTERNATIONAL JOURNAL OF ACADEMIC RESEARCH IN BUSINESS AND SOCIAL SCIENCES

Vol. 9, No. 6, June, 2019, E-ISSN: 2222-6990 @ 2019 HRMARS

BUSD. Berryssa Union School DistrTMK. (2016). $21^{\text {st }}$ Century Learning and the 4Cs. BUSD Education Services.

Carter, J. (2014). The 4Cs of Mathematics Instruction: Collaborate, Create, Communicate, Critique. Westlake High School, Austin, TX.

CCSS. Common Core State Standard. (2014). A Commitment to Student Success: Preparing America's Students for College and Career. Dicapai dari

https://www.svsd410.org/cms/lib/WA01919490/Centricity/Domain/31/Parent\%20CCSS\%20 Presentation.pdf

Coulson, M. (2006). Developing Teachers' Cognitive Clarity and Communication Style through on Insertive Training Program. Doctoral Dissertation, New Castle, New South Wales: Faculty of Education and Arts, University of Newcastle.

Cruickshank, D. R., \& Kennedy, J. J. (1986). Teacher Clarity. Teacher and Teachers Education, 2, 43-67. DOI: http://dx.doi.org/10.1016/0742-051X(86)90004-1.

De Bono, E. (1995). Serious Creativity. The Journal for Quality and Participation, 18(5), 12.

ISTE. International Society for Technology in Education. (2007). ISTE Standards Students. iste.org/standards.

Johor, J. P. N. (2017). Standard Prestasi Pembelajaran Abad Ke-21 Sekolah-sekolah Negeri Johor. www.jpnjohor.moe.gov.my.

Johnson, D. W., \& Johnson, R. T. (2009). Making Cooperative Learning Work. Theory in Practice, 38(2), 67-73. Dicapai dari http://www.jstor.org/stable/1477225.

Kagan, S. (1994). Cooperative Learning. San Ciemente, California, Kagan Publishing.

Kementerian Pendidikan Malaysia. (2013). Pelan Pembangunan Pendidikan Malaysia 2013 - 2025. Dicapai dari https://www.moe.gov.my/images/dasar-kpm/PPP/Preliminary-Blueprint-M.pdf.

Kementerian Pendidikan Malaysia. (2017). Pembelajaran Abad Ke-21; PAK21. Dicapai dari http://upa.ipgkda.edu.my/wp-content/uploads/2017/07/PAK21-KPM.pdf.

Killen, R. (2013). Effective Teaching Strategies: Lessons from Research and Practice. $6^{\text {th }}$ Edition. Cengage Learning, Australia. ISBN: 97801703563290170356329.

Kivunja, C. (2015.a). Exploring the Pedagogical Meaning and Implications of the 4Cs "Super Skills" for the $21^{\text {st }}$ Century through Bruner's $5 E$ Lenses of Knowledge Construction to Improve Pedagogies of the New Learning Paradigm. Creative Education, 6, 224239.http://dx.doi.org/10.4236/ce.2015.62021.

Kivunja, C. (2015.b). Teaching Students to Learn and to Work Well with $21^{\text {st }}$ Century Skills: Unpacking the Career and Life Domain of the New Learning Paradigm. International Journal of Higher Education, 4(1), 1-11.

Levin-Goldberg, J. (2012). Teaching Generation TechX with the 4Cs: Using Technology to Integrate $21^{\text {st }}$ Century Skills. Journal of Instructional Research, 1, 59-66.

Mahamod, Z. (2011). Strengthening Teachers and Students: Teaching and Learning Malay Language in $21^{\text {st }}$ Century. Kertas Kerja Ucaptama di Seminar Bahasa Melayu Singapura 2011. Pusat Bahasa Melayu Singapura, 1 Jun 2011.

Muijis, D., \& Reynolds, D. (2011). Effective Teaching: Evidence and Practice ( $3^{\text {rd }}$ ed.) Los Angeles, CA: Sage. 
NEA. National Education Association. (2010). An Educator's Guide to the "Four Cs". Preparing $21^{\text {st }}$ Century Students for a Global Society.

OMOE. Ontario Ministry of Education. (2016). $21^{\text {st }}$ Century Competencies. Towards Defining $21^{\text {st }}$ Century Competencies for Ontario. Winter 2016 Edition, Phase 1.

P21. Partnership for $21^{\text {st }}$ Century Skills. (2007). The Intellectual and Policy Foundations of the 21st Century Skills Framework. Dicapai dari http://www.p21.org/storage/documents/docs/Intellectual_and_Policy_Foundations.pdf

P21. Partnership for 21st Century Learning. (2012). What We Know About Creativity. Part of the 4Cs Research Series. www.p21.org/storage/documents/docs/Research/P21_4Cs_Research_Brief_Series_Creativit y.pdf.

P21. Partnership for 21st Century Skills. (2014). Learning for the 21st Century. A Report and MILE Guide for 21st Century Skills. Dicapai dari http://www.p21.org/storage/documents/P21_Report.pdf

Rajendran, N. S. (2001). Teaching High Order Thinking Skills: Teachers' Readiness in Conducting Teaching and Learning Process. Seminar/Project Exhibition KBKK: Poster 'WarisanPendidikan-Wawasan'. BPK, KPM.

Salehudin, N. N., Hassan, N. H., \& Hamid, N. A. A. (2015). Mathematics and $21^{\text {st }}$ Century Skills: Students' Perspective. Mathematics Education Journal. 3(1), 24-36. ISSN: 2231-9425.

Taber, K. S. (2018). The Use of Cronbach's Alpha When Developing and Reporting Research Instruments in Science Education. Res Sci Educ, 2018(48), 1273-1296.

Tavakol, M., \& Dennick, R. (2011). Making Sense of Cronbach's Alpha. International Journal of Medical Education, 2011(2), 53-55. ISSN:2042-6372.

The Conference Board, Inc., the Partnership for $21^{\text {st }}$ Century Skills, Corporate Voices for Working Families and the Society for Human Resource Management. (2006). Are They Really Ready for Work? Employers' Perspective on the Basic Knowledge and Applied Skills of New Entrants to the $21^{\text {st }}$ Century U.S. Workforce. ISBN: 0-8237-0888-8.

Torrefranca, E. C. (2017). Developmental and Validation of Instructional Modules on Rational Expressions and Variations. The Normal Lights, 11(1), 43-73.

Yunos, M. (2015). Attitude Realtionship and Students' Perception through Malay Language Learning with $21^{\text {st }}$ Century Skills. Malay Language Education Journal-MyLEJ, 5(2), 22-30. ISSN 21804842. 